\title{
Analisis Soal Ulangan Harian Matematika Kelas IX SMP Negeri 1 Toboali
}

\author{
Eka Rachma Kurniasi*, Yopa, dan Frisyeila Karennisa \\ Pendidikan Matematika, STKIP Muhammadiyah Bangka Belitung, Indonesia \\ *eka.rachmakurniasi@stkipmbb.ac.id
}

\begin{abstract}
Abstrak
Penelitian ini bertujuan untuk menganalisis kemampuan matematis dan kualitas butir soal ulangan harian soal matematika kelas IX SMP Negeri 1 Toboali tahun ajaran 2019/2020. Metode penelitian yang digunakan adalah deskriptif kualitatif. Subjek dalam penelitian ini adalah 36 siswa kelas IX SMP Negeri 1 Toboali tahun ajaran 2019/2020. Instrumen dalam penelitian ini adalah lembar wawancara, soal ulangan harian matematika yang berbentuk essai, lembar validasi ahli. Butir soal dianalisis kualitas butir soal menggunakan Microsoft Office Excel 2016. Hasil yang didapat soal ulangan harian berdasarkan kemampuan matematis terdiri atas pemahaman konsep, komunikasi matematis, penalaran matematis, dan pemecahan masalah matematis. Adapun kualitas butir soal adalah: 1) berdasarkan kriteria tingkat kesukaran diperoleh soal pemahaman konsep berada ditingkat mudah, soal komunikasi matematis berada ditingkat sedang, soal penalaran matematis berada ditingkat sedang, dan soal pemecahan masalah matematis berada ditingkat sukar; 2) berdasarkan kriteria daya pembeda diperoleh soal pemahaman konsep dan komunikasi matematis berdaya beda cukup, soal penalaran matematis berdaya beda baik, dan soal pemecahan masalah matematis berdaya beda sangat baik.
\end{abstract}

Kata kunci: analisis, butir soal, ulangan harian matematika.

Dikirim: 15 Juni 2020

Direvisi: 22 Juni 2020

Diterima: 29 Juni 2020

\section{Identitas Artikel:}

Kurniasi, E. R., Yopa. Y., \& Karennisa, F. (2020). Analisis Soal Ulangan Harian Matematika Kelas IX SMP Negeri 1 Toboali. Ilmu Pendidikan (JIP) STKIP Kusuma Negara, 12(1), 43-52.

\section{PENDAHULUAN}

Pembelajaran mengharuskan adanya proses penilaian di dalamnya. Atau lebih tepatnya evaluasi. Proses ini tidak semata memberikan soal kepada siswa kemudian memberikan skor terhadap jawaban mereka. Lebih jauh evaluasi merupakan proses penilaian hasil belajar siswa yang di dalamnya juga terdapat umpan balik untuk siswa maupun guru. Sejatinya tes tidaklah sama dengan evaluasi, namun tes adalah bagian dari evaluasi itu sendiri.

Evaluasi merupakan kegiatan yang dilakukan guru untuk mengetahui sejauh mana siswa memahami materi pembelajaran (Sapta, 2016). Evaluasi adalah proses mengumpulkan data dasar dan menelaah serta mengambil keputusan dari hasil data dan telaah.

Pelajaran matematika tidak semata-mata disajikan sebagai latihan menghafal rumus dan definisi, tetapi harus lebih ditekankan pada kemampuan memahami soal dan penerapannya dalam menyelesaikan suatu masalah (Rosilawati \& Alghadari, 2018). Proses pembelajaran yang seperti itu tidak sepenuhnya berhasil dalam meningkatkan prestasi belajar siswa. Untuk itu, perlu dilakukan tes atau ulangan sebagai evaluasi pembelajaran untuk mengetahui hasil belajar siswa 
(Suhendri, 2011) dan soal tes atau ulangan perlu dianalisis guna mengetahui soal yang layak digunakan karena soal yang baik akan meningkatkan nilai siswa. Pembelajaran matematika di sekolah maupun di rumah harus dipicu dengan soalsoal matematika yang membutuhkan penalaran (Hidayati \& Widodo, 2015; Siswowijoyo \& Tiya, 2014), trivial, cara penyelesaian tak tunggal, jawaban tak tunggal, dan cara penyelesaian tak trivial, yang memicu keingintahuan siswa terhadap gagasan matematika yang berkaitan.

Ulangan harian merupakan bentuk dari penilaian hasil belajar siswa yang dilakukan untuk melihat sejauh mana siswa memahami materi yang telah disampaikan. Ulangan harian seharusnya digunakan guru sebagai bahan evaluasi apakah materi pada pokok bahasan tersebut sudah sesuai dengan tujuan pembelajaran yang dirancang. Pengadaan ulangan harian merupakan usaha untuk mengukur atau memberikan penghargaan atas kemampuan seseorang yang benarbenar menggambarkan apayang dikuasainya (Anggraeni, 2016). Penilaian yang dilakukan melalui ulangan harian harus sesuai dengan tujuan pembelajaran yang disampaikan pada awal pelajaran dan proses pembelajaran yang dilakukan. Taraf yang diberikan pada saat pembelajaran dan pada saat ulangan harian haruslah setara (Amelia, Susanto \& Fatahillah, 2016). Kesalahan siswa dalam menjawab soal yang diberikan dipengaruhi oleh beberapa faktor seperti kecerdasan, kematangan, guru, orang tua, lingkungan sosial, ataupun dari soal itu sendiri. Ketidaktelitian siswa dalam menjawab soal serta kurangnya pemahaman siswa terhadap materi yang disampaikan juga menjadi faktor kesalahan siswa (Farida, 2015). Dalam beberapa penelitian (misal Sumadiasa, 2014; Minarti, Wahyudin \& Alghadari, 2018; Alghadari \& Herman, 2018) menyatakan bahwa kesalahan yang dilakukan oleh siswa pada materi tertentu yaitu kesalahan konseptual dan kesalahan prosedural dalam menjawab soal. Dengan demikian, perlu dianalisis soal-soal matematika untuk meningkatkan mutu kegiatan belajar mengajar dan akhirnya dapat meningkatkan prestasi belajar matematika (Imswatama \& Muhassanah, 2016).

Kualitas prestasi siswa di kelas dibentuk dari penilaian oleh seorang guru. Oleh karena itu, soal atau instrumen perlu didesain dengan baik. Dengan menggunakan soal yang berkualitas baik, maka dapat dijadikan sebagai salah satu penilaian prestasi belajar siswa yang akurat (Wisnanti, Sunardi \& Trapsilasiwi, 2014). Soal ulangan harus sesuai antara ranah kognitif yang ditetapkan oleh guru dengan ranah kognitif yang sebenarnya menurut Taksonomi Bloom revisi (Effendi, 2017). Mengukur kesesuaian, efisiensi, dan kemantapan suatu instrumen soal dipergunakan kualitas seperti, validitas, reliabilitas, obyekfitas, kepraktisan, tingkat kesukaran, dan daya pembeda.

Beberapa hal yang perlu dilakukan ketika berbicara kualitas butir soal. Antara lain tingkat kesukaran, daya pembeda, dan validitas butir soal. Tingkat kesukaran merupakan peluang siswa menjawab benar suatu soal (Aliati \& Ibrahim, 2013; Son, 2019). Soal dikatakan mudah apabila banyak siswa yang bisa menjawab soal tersebut, soal dikatakan sukar apabila sedikit siswa yang bisa menjawab soal tersebut (Hamzah, 2014). Sedangkan daya pembeda merupakan kemampuan suatu soal dalam membedakan siswa yang berkemampuan tinggi dengan siswa yang berkemampuan rendah (Fatimah \& Alfath, 2019; Son, 2019). Jika kelompok siswa berkemampuan rendah lebih banyak menjawab soal dengan benar dibandingkan kelompok siswa berkemampuan tinggi maka indeks daya pembeda 
bernilai negatif, begitu pula sebaliknya indeks daya pembeda bernilai positif jika kelompok siswa berkemampuan tinggi lebih banyak menjawab soal dengan benar dibandingkan kelompok siswa berkemampuan rendah (Mania, 2012). Validitas adalah ketepatan butir soal dalam mengukur tujuan pembelajaran yang ingin dicapai.

Menurut Budiman \& Jailani (2014) tujuan dari analisis butir soal adalah untuk mengetahui soal ulangan mana yang baik dan mana yang belum baik, dan mengapa soal tersebut dikatakan baik dan belum baik. Sehingga soal tersebut perlu disimpan atau diperbaiki. Validitas dalam penelitian ini akan dilihat yaitu validitas teoritik, apakah soal sudah sesuai dengan indikatornya menurut para ahli. Sedangkan daya pembeda dan tingkat kesukaran akan dianalisis dengan menggunakan rumus dan dibantu program Microsoft Office Excel 2016. Microsoft Office Excel merupakan program pengolahan angka yang umum digunakan dimana penggunaannya relatif mudah dalam memasukkan data, menganalisa data, serta memprosesnya, sehingga program komputer ini cocok digunakan untuk menganalisis butir soal (Purwanti, 2014).

Pada beberapa literatur mengenai instrumen atau soal-soal ulangan harian, disebutkan bahwa guru tidak hanya mengukur ketuntasan materi. Namun diperlukan juga soal-soal yang dapat mengasah keterampilan berpikir lain bagi siswa. Beberapa diantara yang direkomendasikan menurut kurikulum yaitu kemampuan pemahaman konsep, komunikasi matematis dan pemecahaman masalah matematis. Menurut Sumartini (2016) bahwa aktivitas dan soal yang diberikan pada proses pembelajaran siswa adalah bagian dari proses mengasah siswa dengan masalah sehingga diharapkan siswa dapat meningkatkan berbagai kompetensi yang dimilikinya. Selanjutnya Dahar (2011) menyatakan bahwa tujuan utama proses pendidikan adalah meningkatkan kemampuan untuk pemecahan masalah. Selanjutnya kemampuan komunikasi matetis yang menurut para ahli matematika sangat direkomendasikan untuk ditumbuhkan di kalangan siswa. Sebagai salah satu bentuk berpikir dan aktivitas sosial yang direkomendasikan para pakar untuk dikembangkan (Umar, 2012). Lebih lanjut kemampuan pemahaman konsep matematis adalah kemampuan dasar yang harus dimilki oleh peserta didik, ini jelas tertulis dalam kurikulum 2013. Namun disamping itu semua, pembuatan soal juga harus melihat kemampuan siswa dimana dalam penelitian (Kurniasi \& Juwita, 2019) menyatakan bahwa dengan kemampuan yang tinggi pada peserta didik maka cenderung mereka bisa menjawab soal yang diberikan.

Indikator pemahaman konsep matematis menurut Permendikbud Nomor 58 Tahun 2014 dalam penelitian Aziz \& Hidayati (2019), yaitu: 1) menyatakan ulang konsep yang telah dipelajari; 2) mengklasifikasi objek-objek berdasarkan dipenuhi tidaknya persyaratan yang membentuk konsep tersebut; 3) mengidentifikasi sifatsifat operasi atau konsep; 4) menerapkan konsep secara logis. 5) memberikan contoh atau contoh kontra; 6) menyajikan konsep dalam berbagai macam bentuk representasi matematis (tabel, grafik, diagram, sketsa, model matematika atau cara lainnya); 7) mengaitkan berbagai konsep dalam matematika maupun diluar matematika; 8) mengembangkan syarat perlu dan atau syarat cukup suatu konsep. Indikator komunikasi matematis menurut Sumarmo dalam penelitian Husna, Ikhsan \& Fatimah (2013), yaitu: 1) menghubungkan benda nyata, gambar, dan diagram ke dalam ide matematika; 2) menjelaskan ide, situasi dan relasi 
matematika secara lisan atau tulisan dengan benda nyata, gambar, grafik atau bentuk aljabar; 3) menyatakan peristiwa sehari-hari dalam bahasa atau simbol matematika; 4) mendengarkan, berdiskusi dan menulis tentang matematika; 5) membaca presentasi matematika tertulis dan menyusun pertanyaan yang relevan. 6) membuat konjektur, menyusun argumen, merumuskan definisi dan generalisasi. Indikator pemecahan masalah matematis menurut Sumarmo dalam penelitian Husna dkk. (2013), yaitu: 1) mengidentifikasi unsur yang diketahui, dinyatakan, dan kecukupan unsur; 2) membuat model matematika; 3) menerapkan strategi menyelesaikan masalah dalam atau di luar matematika; 4) menjelaskan/menginterpretasi hasil; 5) menyelesaikan model matematika dan masalah nyata; 6) menggunakan matematika secara bermakna.

Adapun dalam penelitian ini akan didefinisikan kemampuan pemahaman konsep meliputi menyatakan ulang konsep, memberikan contoh dan non-contoh, menyajikan konsep dalam bentuk jawaban soal matematika. Adapun kemampuan komunikasi matematis didefinisikan menghubungkan konsep matemtika dengan kehidupan nyata, menjelasankan situasi dengan konsep matematika, menyatakan peristiwa sehari-hari dalam bentuk matematika. Kemampuan pemecahan masalah matematis didefinisikan mengidentifikasi unsur yang diketahui, membuat model matematika, menerapkan strategi menyelesaikan masalah matematika pada soal matematika atau masalah sehari-hari, menjelaskan hasilnya dan memeriksa kembali jawaban.

Mengacu Matematika yang diajarkan di SMA cenderung sudah tinggi tingkat pemahamannya. Oleh karena itu seharusnya tes yang diberikan oleh guru pun sudah harus mengukur beberapa kemampuan dalam bermatematika. Karena tes tidak hanya mengukur skor pemahaman siswa akan materi tersebut, lebih jauh harus mengukur bagaimana tingkat kemampuan berpikir matematis lain misalnya komunikasi, pemecahan masalah, pemahaman konsepnya.

Pentingnya kemampuan pemecahan masalah dan komunikasi matematis di era sekarang mengharuskan guru menyusun sebuah soal tes matematika yang mencakup indikator kemampuan tersebut. Soal yang tepat tentunya dapat mengukur sejauh mana kemampuan komunikasi matematis dan pemecahan masalah siswa. Evaluasi berfokus pada nilai dan apa yang telah dipelajari siswa, memotret konten atau materi yang tingkat penguasaan siswa terhadap pembelajaran (Rahim, 2019).

Berdasarkan beberapa tinjauan di atas maka peneliti menganalisis indikator butir soal ulangan harian yang digunakan oleh guru matematika pada salah satu SMA di Toboali Bangka Selatan. Serta mengukur kualitas butir soal ulangan harian mencakup tingkat kesukaran dan daya pembeda.

\section{METODE PENELITIAN}

Penelitian ini merupakan penelitian dengan pendekatan deskriptif kualitatif dengan maksud untuk menjelaskan keadaan sesuai objek yang diteliti bukan untuk menolak atau menerima hipotesis. Subjek dalam penelitian ini adalah 36 siswa kelas IX SMP Negeri 1 Toboali tahun ajaran 2019/2020. Instrumen dalam penelitian ini adalah lembar wawancara, lembar soal ulangan harian matematika yang berbentuk essai, dan lembar validasi ahli. Teknik pengumpulan data adalah dokumentasi dan wawancara dengan guru matematika kelas IX SMP Negeri 1 
Toboali. Analisis data menggunakan program komputer Microsoft Office Excel 2016 yang hasilnya mencakup pengukuran tingkat kesukaran dan daya pembeda. Sedangkan analisis indikator soal ulangan dilakukan validasi teoritik dari ahli apakah ulangan harian sudah mencakup indikator kemampuan pemahaman konsep, komunikasi matematis, dan pemecahan masalah. Validasi ahli dalam analisisnya yaitu dua orang dosen evaluasi pembelajaran matematika.

\section{HASIL DAN PEMBAHASAN}

\section{Analisis Kemampuan Matematis dalam Soal}

Berdasarkan hasil analisis dari validasi teoritik oleh ahli didapatlah kemampuan matematia yang terlihat dalam soal ulangan harian yang dibuat guru. Yaitu pemahaman konsep matematis, penalaran matematis, komunikasi matematis, dan pemecahan masalah matematis. Lebih lengkapnya disajikan dalam Tabel 1.

\section{Tabel 1. Soal Ulangan Harian Matematika Kelas IX SMP Negeri 1 Toboali}

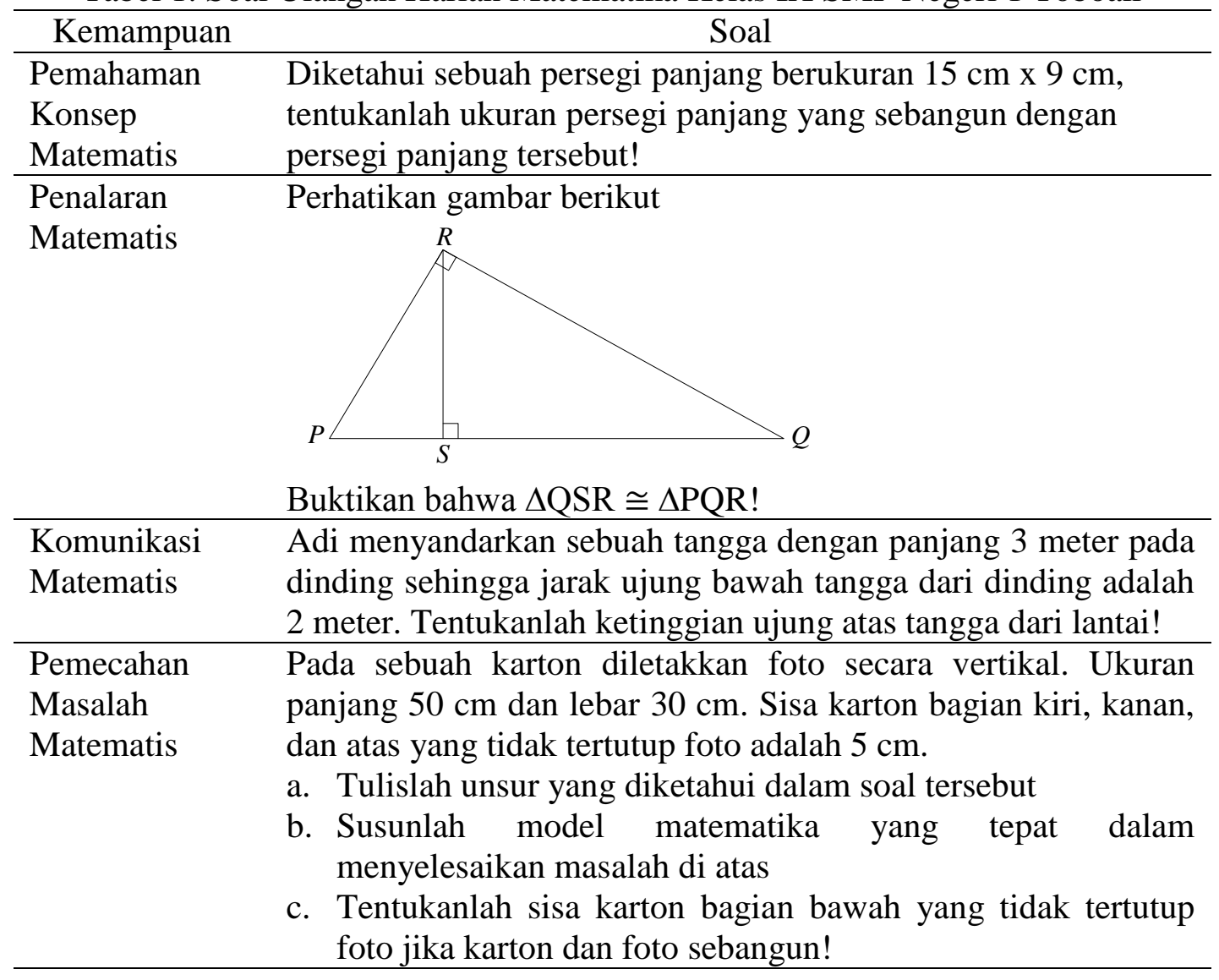

Berdasarkan Tabel di atas, bahwa kemempuan yang muncul dalam soal ulangan harian yang diberikan guru mencakup pemehaman konsep, penalaran, komunikasi matematis, dan pemecahan masalah. Namun secara lengkap jika melihat kemabali indikator pada setiap kemampuan belum mencakup keseluruhannya. Misalnya kemampuan pemahaman konsep: 1) soal belum terlihat adalanya indokator memberikan contoh dan non-contoh; 2) menyajikan konsep dalam bentuk matematika. Indikator yang muncul hanya menyatakan ulang 
sebuah konsep. Secara tingkat berpikir pada Tasonomi Bloom, soal ini masih termasuk kemampuan berpikir tingkat rendah. Kemudian pada indikator kemampuan komunikasi matematis yang muncul adalah menghubungkan konsep matematika dengan kehidupan nyata, komunikasi matematis didefinisikan menghubungkan konsep matemtika dengan kehidupan nyata, dan menyatakan peristiwa sehari-hari dalam bentuk matematika. Namun soal ini belum secara terperinci membuat pertanyaan atas ketiga indikator tersebut. Satu soal mencakup tiga indikator secara langsung. Pada soal kemampuan pemecahan masalah matematis, muncul tiga indikator yaitu mengidentifikasi unsur yang diketahui, membuat model matematika dan menerapkan strategi dalam menyelesaikan masalah pada soal. Namun indikator menjelaskan hasil dari startegi pemecahan masalah dan memeriksa kembali jawaban tidak nampak pada soal ini. Secara umum untuk soal pemecahan masalah matematis guru lebih terarah dalam menyusunnya. Terlihat dari setiap indikator yang muncul dituliskan memalui pertanyaan pada soal tersebut. Ada satu lagi kemampuan yang muncul pada soal ulangan harian ini yaitu soal penalaran matematis. Indikator yang terlihat adalah siswa diminta untuk membuktikan konsep matematika dari unsur yang diketahui.

\section{Analisis Tingkat Kesukaran dan Daya Pembeda}

Analisis berikutnya yang dilakukan adalah kualitas butir soal mencakup tingkat kesukaran dan daya pembeda. Analisis ini dilakukan dengan mengunakan rumus dan bantuan Microsoft Office Excel 2016. Adapun rumus yang digunakan untuk menghitung Tingkat Kesukaran adalah

$$
I K=\frac{\bar{x}}{b}
$$

Keterangan:

$I K=$ Indeks Kesukaran

$\bar{x}=$ rerata skor siswa

$b=$ bobot soal

Berdasarkan hasil perhitungan diperoleh skor berikut untuk tingkat kesukaran setiap butir soal, disajikan pada Tabel 2.

Tabel 2. Hasil Tingkat Kesukaran Butir Soal

\begin{tabular}{lcc}
\hline \multicolumn{1}{c}{ Kemampuan } & Indeks & Kriteria \\
\hline Pemahaman Konsep Matematis & 0,72 & Mudah \\
\hline Penalaran Matematis & 0,61 & Sedang \\
\hline Komunikasi Matematis & 0,50 & Sedang \\
\hline Pemecahan Masalah Matematis & 0,28 & Sukar \\
\hline
\end{tabular}

Berdasarkan Tabel tingkat kesukaran butir soal ulangan harian matematika kelas IX SMP Negeri 1 Toboali tersebutdiperoleh soal pemahaman konsep matematisyang berada ditingkat mudah, soal komunikasi matematis berada ditingkat sedang, soal penalaran matematis berada ditingkat sedang, dan soal pemecahan masalah matematis berada ditingkat sukar. Kualitas butir soal yang baik berdasarkan tingkat kesukaran adalah soal yang tingkat kesukarannya sedang 
dengan indeks kesukaran yaitu antara 0,30-0,70. Kualitas butir soal yang cukup baik berdasarkan tingkat kesukaran adalah soal yang tingkat kesukarannya mudah atau sukar dengan indeks kesukaran untuk tingkat mudah yaitu di bawah 0,30 dan indeks kesukaran untuk tingkat sukar yaitu di atas 0,70 .

Analisis kualitas butir soal berikutnya adalah data pembeda. Adapun rumus yang digunakan untuk menghitung daya pembeda adalah:

$$
D P=\frac{\overline{X_{A}}-\overline{X_{B}}}{b}
$$

Keterangan :

$D P=$ Daya Pembeda

$\overline{X_{A}}=$ rerata skor siswa kelompok atas

$\overline{X_{B}}=$ rerata skor siswa kelompok bawah

$b=$ bobot soal

Berdasarkan hasil perhitungan daya pembeda butir soal, diperoleh hasil sebagai berikut pada Tabel 3.

Tabel 3. Hasil Daya Pembeda Butir Soal

\begin{tabular}{lcc}
\hline \multicolumn{1}{c}{ Model Soal } & Indeks & Kriteria \\
\hline Pemahaman Konsep Matematis & 0,26 & Cukup \\
\hline Penalaran Matematis & 0,52 & Baik \\
\hline Komunikasi Matematis & 0,34 & Cukup \\
\hline Pemecahan Masalah Matematis & 0,73 & Sangat Baik \\
\hline
\end{tabular}

Berdasarkan Tabel daya pembeda butir soal ulangan harian matematika kelas IX SMP Negeri 1 Toboali tersebut diperoleh soal pemahaman konsep matematis dan komunikasi matematis berdaya beda cukup, soal penalaran matematis berdaya beda baik, dan soal pemecahan masalah matematis berdaya beda sangat baik.

Kualitasi butir soal yang baik berdasarkan daya pembeda adalah soal dengan daya pembeda baik atau sangat baik dengan indeks daya pembeda baik yaitu antara 0,40-0,70 dan indeks daya pembeda sangat baik yaitu di atas 0,70.

Peneliti juga melakukan wawancara kepada salah satu guru yang memberikan soal ulangan tersebut. Hal tersebut dibenarkan bahwa dalam melakukan ulangan harian, guru mengukur kemampuan pemahaman konsep yang utama. Namun tidak menutup kemungkinan kemampuan lainnya. Dalam melakukan ulangan harian soal yang diberikan oleh guru diutamakan adalah soal yang dapat mengukur apakah siswa sudah paham konsep/materi yang diberikan atau belum. Mengenai kemampuan matematis yang muncul pada soal, disesuaikan dengan tujuan pembelajaran yang sudah disusun sebelumnya. Namun guru menyatakan bahwa tidak menghitung secara langsung kualitas butir soal. Guru melihat kualitas butir soal berpatokan pada soal-soal yang sebelumnya sudah pernah diberikan dengan tipe yang sama dan soal-soal yang tersedia di buku.

Berdasarkan hasil yang diperoleh di atas, adanya kemampuan matematika tingkat tinggi pada soal ulangan harian yang diberikan oleh guru kepada siswanya. Muncul satu kemampuan yang awalnya tidak masuk, yaitu kemampuan penalaran 
matematis. Namun pada soal-soal tersebut belum mencakup semua indikator pada kemampuan komunikasi matematis, penalaran matematis, dan pemecahan masalah matematis. Jenis kemampuan yang muncul pada soal ulangan harian baru kemampuan berpikir tingkat rendah. Padahal pada teori evaluasi seharusnya instrumen yang disusun guru mengarahkan pada kemampuan tingkat tinggi. Penilaian soal-soal dengan tipe Higher Order Tkinking Skills (HOTS) dalam pembelajaran sangat direkomendasikan karena penilaian berbasis HOTS ini mampu meningkatkan mutu pendidikan. Sedangkan soal tipe Lower Order Thinking Skills (LOTS) hanya terbatas pada penggunaan pikiran (Warmi, Adirakasiswi \& Imami, 2019). Namun pada soal kemampuan penalaran matematis, sudah mengarahkan pada kemampuan HOTS. Berdasarkan tingkatan bahwa pada tahap analisis siswa membutuhkan proses penalaran matematis di dalamnya (Rahim, 2019). Sehingga ini bisa jadi latihan kepada siswa menuju kemampuan HOTS.

Selanjutnya untuk kualitas butir soal. Tingkat kesukaran butir soal. Butir soal dengan tingkat mudah merupakan soal yang materinya mudah dipahami siswa. Butir soal dengan tingkat sukar merupakan soal yang materinya butuh pemahaman tinggi dan perlu ketelitian dalam perhitungan. Soal yang baik adalah soal yang tingkatnya tidak terlalu mudah atau tidak terlalu sukar karena soal yang terlalu mudah tidak bisa merangsang siswa untuk berusaha keras memecahkan soal. Sebaliknya, soal yang terlalu sukar membuat siswa beranggapan bahwa mereka tidak bisa menyelesaikannya sehingga membuat mereka tidak bersemangat lagi dan menyerah (Arikunto, 2012). Sebaiknya sebuah soal yang baik harus mencakup dari level mudah, sedang, dan sulit (Suherman, 2010). Adapun pada penelitian ini soal yang dibuat oleh guru mencakup kriteria mudah, sedang, dan sukar.

Kualitas butir soal yang diukur berikutnya yaitu daya pembeda. Soal yang baik adalah soal yang dapat membedakan antara siswa yang paham serta menguasai materi dengan siswa yang kurang paham dan kurang menguasai materi. Soal yang cukup baik adalah soal yang bisa dijawab secara kebetulan oleh siswa yang kurang paham dan kurang menguasai materi (Halik, Mania \& Nur, 2019). Kualitas butir soal yang cukup baik berdasarkan daya pembeda adalah soal dengan daya pembeda cukup dengan indeks daya pembeda yaitu antara 0,20-0,40. Adapun pada penelitian ini daya pembeda nya pada kriteria cukup, baik, dan sangat baik.

\section{KESIMPULAN}

Berdasarkan hasil analisis butir soal ulangan harian matematika kelas IX SMP Negeri 1 Toboali dapat disimpulkan terdapat empat kemampuan matematis yang muncul pada soal. Yaitu kemampuan pemahaman konsep, penalaran matematis, komunikasi matematis, dan pemecahan masalah. Namun tidak semua indikator kemampuan tersebut muncul pada soal. Selain itu tidak semua soal tertulis jelas perintah pengerjaannya berdasarkan indikator kemampuan matematis yang muncul.

Mengenai kualitas butir soal untuk tingkat kesukaran, soal kemampuan pemahaman konsep matematis pada tingkatan mudah, soal penalaran matematis pada tingkatan sedang, soal komunikasi matematis pada tingkatan sedang, dan 
soal pemecahan masalah matematis pada tingkatan sukar. Daya pembeda soal, pada soal kemampuan pemahaman konsep matematis dengan level cukup, soal penalaran matematis dengan level baik, soal komunikasi matematis dengan level cukup, dan soal pemecahan masalah matematis dengan level sangat baik.

\section{REFERENSI}

Alghadari, F., \& Herman, T. (2018). The obstacles of geometric problem-solving on solid with vector and triangle approach. JPhCS, 1132(1), 012046.

Aliati., \& Ibrahim, M. (2013). Kualitas Tes Ujian Nasional Matematika Siswa SMP Negeri di Kabupaten Buton Utara Tahun Ajaran 2011/2012. Jurnal Penelitian Pendidikan Matematika, 1(1), 1-10.

Amelia, D., Susanto, S., \& Fatahillah, A. (2016). Analisis Hasil Belajar Matematika Siswa pada Pokok Bahasan Himpunan Berdasarkan Ranah Kognitif Taksonomi Bloom Kelas VII-A di SMPN 14 Jember. Jurnal Edukasi, 2(1), 1-4.

Anggraeni, L. (2016). Peningkatkan Kompetensi Guru Menyusun Butir Soal Bermutu melalui Program Workshop. Jurnal Inovasi Pembelajaran Karakter, 1(2), 1-9.

Arikunto, S. (2012). Dasar-Dasar Evaluasi Pendidikan. Jakarta: Bumi Aksara.

Aziz, H. E., \& Hidayati, N. (2019). Analisis Kemampuan Penalaran Matematis Siswa SMP pada Materi Aritmatika Sosial. In Prosiding Seminar Nasional Matematika dan Pendidikan Matematika (Sesiomadika), 2(1c), 824-828.

Budiman, A., \& Jailani, J. (2014). Pengembangan Instrumen Asesmen Higher Order ThinkingSkill (HOTS) pada Mata Pelajaran Matematika SMP Kelas VIII Semester 1. Jurnal Riset Pendidikan Matematika, 1(2), 139-151.

Dahar, R. W. (2011). Teori-teori Belajar dan Pembelajaran. Jakarta: Erlangga

Effendi, R. (2017). Konsep Revisi Taksonomi Bloom dan Implementasinya pada Pelajaran Matematika SMP. JIPMat, 2(1), 72-78.

Farida, N. (2015). Analisis Kesalahan Siswa SMP Kelas VIII dalam Menyelesaikan Masalah Soal Cerita Matematika. AKSIOMA: Jurnal Program Studi Pendidikan Matematika, 4(2), 42-52.

Fatimah, L. U., \& Alfath, K. (2019). Analisis Kesukaran Soal, Daya Pembeda dan Fungsi Distraktor. Journal Al-Manar, 8(2), 37-64.

Halik, A. S., Mania, S., \& Nur, F. (2019). Analisis Butir Soal Ujian Akhir Sekolah (UAS) Mata Pelajaran Matematika pada Tahun Ajaran 2015/2016 SMP Negeri 36 Makassar. Al asma: Journal of Islamic Education, 1(1), 11-17.

Hamzah, A. (2014).Evaluasi Pembelajaran Matematika. Jakarta: Rajawali Pers.

Hidayati, A., \& Widodo, S. (2015). Proses Penalaran Matematis Siswa dalam Memecahkan Masalah Matematika pada Materi Pokok Dimensi Tiga Berdasarkan Kemampuan Siswa di SMA Negeri 5 Kediri. Jurnal Math Educator Nusantara: Wahana Publikasi Karya Tulis Ilmiah di Bidang Pendidikan Matematika, 1(2), 131-143.

Husna, H., Ikhsan, M., \& Fatimah, S. (2013). Peningkatan Kemampuan Pemecahan Masalah dan Komunikasi Matematis Siswa Sekolah Menengah Pertama melalui Model Pembelajaran Kooperatif Tipe Think-Pair-Share (TPS). Jurnal Peluang, 1(2), 81-92. 
Imswatama, A.,\& Muhassanah, N. (2016). Analisis Kesalahan Mahasiswa dalam Menyelesaikan Soal Geometri Analitik Bidang Materi Garis dan Lingkaran. Suska Journal of Mathematics Education, 2(1), 1-12.

Kurniasi, E. R., \& Juwita, I. (2019). Analisis Kemampuan Pemahaman Konsep Matematis Mahasiswa Ditinjau dari Kemampuan Tinggi, Sedang, Rendah. Edutainment, 7(1), 21-34.

Mania, S. (2012). Pengantar Evaluasi Pengajaran. Makassar: Alauddin University Press.

Minarti, E. D., Wahyudin., \& Alghadari, F. (2018). Student's conceptions and geometry problem-solving of the distance in cube. JPhCS, 1132(1), 012033.

Purwanti, M. (2014). Analisis Butir Soal Ujian Akhir Mata Pelajaran Akuntansi Keuangan Menggunakan Microsoft Office Excel 2010. Jurnal Pendidikan Akuntansi Indonesia, 12(2), 81-94.

Rahim, F. (2019). How To Steam Your Classroom. Jakarta: Agtifindo.

Rosilawati, R., \& Alghadari, F. (2018). Konsepsi Siswa pada Suatu Bentuk Bangun Ruang Terkait dengan Rusuk dan Diagonal Sisi. Prisma, 7(2), 164176.

Sapta, A. (2017). Pengaruh Penggunaan Quiz Creator Terhadap Hasil Belajar Matematika Siswa. Jurnal Mathematic Paedagogic, 1(1), 91-96.

Siswowijoyo, M., \& Tiya, K. (2017). Deskripsi Kemampuan Literasi Matematika Siswa Kelas IX SMP Negeri di Kota Raha. Jurnal Penelitian Pendidikan Matematika, 2(2), 73-90.

Son, A. L. (2019). Instrumentasi Kemampuan Pemecahan Masalah Matematis: Analisis Reliabilitas, Validitas, Tingkat Kesukaran dan Daya Beda Butir Soal. Gema Wiralodra, 10(1), 41-52.

Suhendri, H. (2011). Pengaruh Kecerdasan Matematis-Logis dan Kemandirian Belajar terhadap Hasil Belajar Matematika. Formatif: Jurnal Ilmiah Pendidikan MIPA, 1(1), 29-39.

Suherman, E. (2010). Evaluasi Pembelajaran Matematika. Bandung: Universitas Pendidikan Indonesia.

Sumadiasa, I.G. (2014). Analisis Kesalahan Siswa Kelas VIII SMP Negeri 5 Dolo dalam Menyelesaikan Soal Luas Permukaan dan Volume Limas. Jurnal Elektronik Pendidikan Matematika Tadulako, 1(2), 197-208.

Sumartini, T. S. (2016). Peningkatan Kemampuan Pemecahan Masalah Matematis Siswa melalui Pembelajaran Berbasis Masalah. Mosharafa: Jurnal Pendidikan Matematika, 5(2), 148-158.

Umar, W. (2012). Membangun Kemampuan Komunikasi Matematis dalam Pembelajaran Matematika. Infinity Journal, 1(1), 1-9.

Warmi, A., Adirakasiswi, A. G., \& Imami, A. I. (2019). Analisis Soal Penilaian Akhir Semester Mata Pelajaran Matematika SMP Berdasarkan Level Berpikir. Jumlahku: Jurnal Matematika Ilmiah STKIP Muhammadiyah Kuningan, 5(2), 53-63.

Wisnanti, A., Sunardi, S., \& Trapsilasiwi, D. (2014). Pengembangan Instrumen Penilaian Metakognisi Siswa Sekolah Menengah Pertama Dalam Menyelesaikan Soal Cerita Matematika Pada Pokok Bahasan Teorema Pythagoras Kelas VIII. KadikmA, 5(1), 77-86. 